\begin{tabular}{|c|c|}
\hline & Volume \& Issues Obtainable at The Women University Multan \\
\hline
\end{tabular}

\title{
Weak Institutions and Persistence of Slums in Bihar, India
}

\author{
Abodh Kumar', Muhammad Ramzan Sheikh ${ }^{2}$, Kashif Saeed ${ }^{3}$ \\ ${ }^{1}$ Assistant Professor, Centre for Economic Studies and Policies (CESP), Central University of South Bihar, \\ Gaya, Bihar, India. \\ ${ }^{2}$ Associate Professor, School of Economics, Bahauddin Zakariya University Multan, Pakistan. \\ ${ }^{3}$ Department of Accounting and Finance, The Islamia University of Bahawalpur, Pakistan.
}

\begin{tabular}{lr}
\hline ARTICLE DETAILS \\
\hline History: & May 18, 2021 \\
Received: & September25, 2021 \\
Review: & October 08, 2021 \\
Accepted: & Available \\
Online:October 08, 2021
\end{tabular}

\section{Keywords:}

Slums, Weak Institutions,

Governance, Patronage, Perceived

Property Rights, Human Capital.

\section{DOI:}

10.52700/assap.v2i2.57

\section{ABSTRACT}

This study endeavors to answer two questions: (a) why do slums persist? and (b) How can we transform slums into better living spaces? Small city slums have been largely overlooked in the existing literature on urbanization. The study utilizes primary data collected from 184 households and focus group discussions conducted in nine different slums of Gaya, a small city of Bihar in India. Econometric results reveal that perceived legal ownership, prolonged stay at the same location, income and education facilitate the dissolution of slum attributes, as defined by UNHabitat. Our results also suggest that although patronage associated with corruption within the local formal governance enables reduction of slum characteristics, discriminatory allocation of public resources contributes to their persistence. The paper suggests that strengthening of security of land tenure, improvement in local governance, and adoption of income and human capital augmenting measures can act as a potential catalyst towards the endeavor to de-slum a city.

(C) 2021 The Authors, Published by WUM. This is an Open Access Article under the Creative Common Attribution Non Commercial 4.0

Corresponding author's email address: ramzansheikh@bzu.edu.pk

\section{Introduction}

UN-Habitat (2016) defines a slum household as, "a household in which the inhabitants suffer one or more of the following household deprivations: lack of access to an improved water source, lack of access to improved sanitation facilities, lack of sufficient living area, lack of housing durability and lack of security of tenure". The persistence of these physical and legal deprivations is tantamount to the persistence of slums whereas, their dissolution leads to construct a slum-free city. This paper seeks to find persuasive factors behind the sustenance and removal of these deprivations. Considering the immense contributions of slum dwellers in the economic space of the city, the study circumvents the possibility of forceful eviction of slums. Rather, the argument is, if these deprivations persist then slums persist. In this context, this paper attempts to answer two interweaved questions: (a) why do slums persist? In other 
words, what are the factors, which uphold the slum deprivations? and (b) what are the required steps to attenuate these formidable deprivations?

Labour is the prime endowment of poor incumbents who enter the economic space of a city. They prefer labor effort over leisure and queued up in the urban informal labor market to earn wages. Their wages determine their reservation prices to buy wage goods and investment goods like housing, health, education for children, etc. The large gap between reservation prices of buyers and sellers for rented accommodation in the urban housing market compels the former to take shelter in slums. Thus, choosing a slum for shelter is a forced and restricted choice yet a rational decision by a slum dweller, when market failure in the non-slum housing market unites with indifferent public order.

Slum formation is exclusively an urban phenomenon. According to a report on slum formation in India (GoI 2015), "The main reason for slum proliferation is rapid and noninclusive patterns of urbanization catalyzed by increasing rural migration to urban areas". During the post-independence period, the Indian economy has experienced multiple structural transformations and succeeded in achieving a sustainable high rate of growth led by the movement of resources from slow growing sectors towards fast growing sectors (Wallack, 2003). Sustainable change in GDP composition away from the primary sector has analytically moved together with the pace of urbanization ${ }^{1}$. The rising slum population followed the pace of urbanization ${ }^{2}$. Slum statistics (Table1) show that the decadal (2001-11) growth of urbanization has been estimated at nearly 32 percent, while, the slum population growth rate was 25 percent during the same decade. During 2001-2011, India has accommodated 13.1 million people in slums however the slum populations' share of the urban population decreased. A total of 65.49 million inhabitants living in 13.9 million households have been enumerated in slums of 2613 cities/towns (GoI, 2015).

Table1: Slum Statistics in India and Bihar

\begin{tabular}{|c|c|c|c|c|c|c|c|c|c|c|}
\hline \multirow[t]{2}{*}{ Year } & \multicolumn{2}{|c|}{ Total Population } & \multicolumn{2}{|c|}{$\begin{array}{c}\text { Urban } \\
\text { Population } \\
\text { (million) }\end{array}$} & \multicolumn{2}{|c|}{$\begin{array}{c}\text { The proportion } \\
\text { of Urban } \\
\text { Population to } \\
\text { Total Population }\end{array}$} & \multicolumn{2}{|c|}{$\begin{array}{c}\text { Slum Population } \\
\text { (million) }\end{array}$} & \multicolumn{2}{|c|}{$\begin{array}{c}\text { Slum } \\
\text { Population in } \\
\text { Proportion of } \\
\text { Urban } \\
\text { Population } \\
\end{array}$} \\
\hline & $\begin{array}{c}\text { India } \\
\text { (billion) }\end{array}$ & $\begin{array}{c}\text { Bihar } \\
\text { (million) }\end{array}$ & India & Bihar & India & Bihar & India & Bihar & India & Bihar \\
\hline 2001 & 1.028 & 82.9 & 286.1 & 8.6 & $27.81 \%$ & $10.46 \%$ & 52.3 & 0.53 & $18.3 \%$ & $6.2 \%$ \\
\hline 2011 & 1.210 & 10.4 & 377.1 & 11.7 & $31.14 \%$ & $11.29 \%$ & 65.4 & 1.2 & $17.4 \%$ & $10.53 \%$ \\
\hline
\end{tabular}

Slums are dynamic socio-economic sites where urban poor live with their aspirations to splinter the fetters of poverty. Slum-dwellers interlace the productive fabric of the city. The crowd in occupations in which the city's non-slum residents endeavor to keep themselves off. They contribute to capital formation in urban as well as in rural areas of which they are part. Children of slums are major consumers of education provided by government-run schools (Banerjee et al. 2012) and private schools with a low capital base. Slums provide shelter to rag-pickers who contribute to the cleanliness of the city's environment. Here, the paradox of slum life appears. Slum dwellers' services are avidly required across the economic sphere of

\footnotetext{
${ }^{1}$ Michaels, Rauch and Redding. (QJE, 2010) have provided empirical evidence between structural transformation and urbanisation.

${ }^{2}$ Davis (1965, p. 41) defines urbanisation as "The proportion of the total population concentrated in urban settlements, or else to a rise in this proportion".
} 
a city, but they are unwelcomed in the non-slum housing market. Moreover, Slums generate negative externalities in respect of health risks (Duflo et al. 2012) and are the repository for the negative externalities of the city - illegal, polluting, and dangerous activities (UNHabitat-2003). Poor physical infrastructure like improved drinking water, sanitation facilities, high incidence of health problems, the high opportunity cost of dwellers to access public health; facilities, exclusion from the formal financial market for credit are few added disadvantages of living in a slum. Slum children encounter higher rates of drop-out in comparison to non-slum children in the city (Small and Newman, 2001). Arimah and Branch (2011) call slums a physical manifestation of social exclusion where, slum residents are excluded from participating in the economic social, political, and cultural spheres of the city. Fox (2008) identifies slums as 'high transaction cost zones,' and deliberates that their presence is evidence of spatially uneven economic governance. In such a context, the costs associated with slums may mitigate the potential benefits of urban growth. Moreover, transaction costs in slums can be understood with reference to frequent health problems due to poor access to improved water, sanitation, drainage, and over-crowded living conditions. Despite the prevailing disadvantages of slums, a city requires slum dwellers to roll its functioning.

The paper is organized as follows: Section 1 introduces the case of slums and their associated advantages and disadvantages. Section 2 discusses the literature and fleshes out fundamental institutional issues associated with the proliferation and persistence of Slums. Section 3 discusses the key features of the primary data collected from the field site, viz., Gaya, a small city in Bihar, India. Section 4 presents an econometric model while section 5 discusses the results. And finally, Section 6 concludes along with the policy implications.

\section{Persistence of Slums: A Literature Review}

Slums are illegally settled settlements in a city. "Lack of security of tenure" or absence of legal ownership of occupancy is the epicenter of all deprivations that slum households encounter. This can have removed only through legal encapsulation of the occupied dwelling space. Illegal occupancy often convoys with fear of eviction, denial of access to the formal credit market, and vulnerability to exploitation by public officials and political patrons. According to Marx et. al. (2013), ambiguous property and tenancy rights, potentially reduces the efficiency of urban land and housing markets and may discourage investment or reduce participation in urban labor markets. Dafe (2009) in her study on Nairobi slum dwellers found that the lack of formal access to land, housing, and services lead to emergence and persistence of slums". Therefore, Institutional (legal) weakness in terms of the absence of property ${ }^{3}$ rights disintegrates slum households from the formal institutions which are manifested through dilution of their bargaining power to access the public goods. Disavowed legal ownership of dwellings lay the weak foundation of governance structure in slums. As discussed above, apart from legal deprivation (i.e. lack of security of land tenure), slum households encounter physical deprivations like improved housing, water, sanitation, drainage, etc. Constrained by the low income of the slum dwellers and given the nature of the above goods (i.e. public good), the latter requires to be allocated by the government. Several researchers identify the provision and security of property rights as part of good governance

\footnotetext{
${ }^{3}$ Property is not a physical thing that can be photographed or mapped. Property is not the primary quality of an asset, but the legal expression of an economically meaningful consensus about assets. Law is the instrument that fixes and realizes capital (De Soto, 2000).
} 
(see Williamson, 2005; Khan, 2005; Phillips, 2008; Dixit, 2015). Weak governance in slums ends up with poor/no supply of public goods to the target groups. World Bank (2004) associates governance with the effective delivery of public goods and services. The issue of governance in slums begins with a simple question i.e. "How the public goods are allocated under the existing institutional framework?" Governance in slums is pre-dominantly informal, characterized by the influential role of corrupt political patronage or patron-client relationship.

Weak governance in slums creates frictions in the allocation and delivery of public goods. In such socio-economic space, public goods allocation is discriminatory and various coercive interest groups are likely to occupy the centre-stage. These interest groups reformulate the rules of the game and substitute rule-based governance. Therefore, the supremacy of informal over formal governance is the distinguishing feature of governance in slums. The emergence of corrupt political patronage in slums is the manifestation of such an institutional structure. In a cross-section study of more than 150 countries, Kaufmann et al (1999) provide empirical evidence of a strong causal relationship from better governance to better development outcomes. Thus, good and effective governance is crucial to improve the life of slumdwellers. Effective public provisioning of goods and services strengthen an economy in fighting poverty (Dasgupta and Ray 1986, Tebaldi and Mohan, 2010), rising inequality (Deaton and Dreze, 2002), Chong and Gradstein, 2007, Datt et al. 2016), Whereas, poor governance such as leakage in public spending and weak institutional capacity in terms of poor execution and monitoring are possible reasons behind the ineffectiveness of public spending (World bank, 2004; Andrew et al., 2008). Marx et al. (2013) in their study on slums of developing countries identified multiple market and policy failures, acute governance, and coordination problems in slums which lead to poverty trap and low human capital formation. Many scholars (Sharma and Bhide 2005; Besley and Ghatak, 2006; Ross, 2006,) noted the adverse effect of weak public goods provisioning on the poor. Ahluvalia (2019), Mahabir et al. (2016) identify challenges associated with governance that resulted in a significant deterioration in the state of public services and proliferation of slums in cities of India. Fox (2013) proposed that slums are the manifestation of "disjointed modernization" in which urban population growth outpaces urban economic and institutional development. Zhang (2017), took the underpinning of the "Credibility thesis" " proposed by Ho (2014) and argues in his study that slums persist because they satisfy certain functions for social, economic, and political actors, regardless of their levels of informality, illegality, and physical inadequacy.

Slum dwellers of small city slums are short distant migrants who sustain strong rural linkages. Small city slums are distinguished by large city slums on carrying stronger rural social attributes and are more homogeneous socio-cultural spaces. Large shifting of living space from rural to urban areas has seized the attention of political parties to shift their vote share estimates towards expanding urban clusters. They perceive slum dwellers as their potential voters. If a political party succeeds in earning political loyalties of dwellers in small city slums, then, they can claim their voting share in rural areas too, may contrary to large city slums. Therefore, slums are politically dynamic spaces where many parties compete to anchor. As discussed in the previous section, the epicenter of the vulnerability of slum dwellers is "the lack of secure land tenure", tied with fear of eviction. This vulnerability of slum dwellers compels them to adopt "Self-preservation" as their core strategy. Selfpreservation refers to "insecure feet seek secure grip". This means that slum dwellers want

${ }^{4}$ Institutional function presides over form; the former can be expressed by its credibility, that is, the perceived social support at a given time and space. This postulate has here been dubbed the "credibility thesis". 
secure land tenure for their dwellings that formal institutions often deny. This gives birth to patronage politics or political clientelism in slums.

Patronage is an informal institutional arrangement, based on quid-pro-quo or exchange relationship between the patron and clients (here, local elected representatives and slumdwellers respectively). Such a relationship is characterized by unequal power relations between the patron and clients. Eisenstad and Roniger (1980) emphasized that monopolization of power with the patron is of crucial importance for the clients. Monopoly power empowers the patron to exploit the vulnerability of the clients with discriminatory and discretionary favors. Piliavsky (2014) calls patronage in India is "a pervasive social norm". The plethora of literature available on political clientelism with reference to the exchange of votes for discriminatory favor (Weingrod, 1968; Chandra, 2007; Jha, Rao and Woolcock, 2007; Berenschot, 2011; Gonzalez-Ocantos et al., 2012; Robinson and Verdier, 2013; Auerbech, 2016). Here, it is pertinent to argue that if we restrict our argument that political patronage is based on the exchange of "votes" and "protection from eviction" then numerous patrons compete in a slum location. To play the role of patron, it is not necessary to hold a public office. The most significant aspect of political patronage in slums is the patron's assurance to slum dwellers against possible eviction from their current dwelling. During our Focussed-Group Discussions (FGDs) in various slums, it has been informed that representatives of all political parties offer them protection from possible eviction. This appears as a substitute for the legal security of land tenure. Moreover, in slums, it is the patron (local elected representative) who decides the allocation of public goods to the clients (i.e. slum dwellers). The local elected representative also provides discriminatory access to slum dwellers to access benefits from various government run welfare schemes like Public Distribution System (PDS), access to fund for toilet construction under Swachh Bharat Abhiyan (Clean India Mission), etc. Being beneficiaries of these schemes, slum dwellers develop the perception that they are the natural claimant of the occupied land in the slum. The perception gets strengthened with a prolonged stay at the same location in a slum.

A growing body of literature calls attention to the fact that residents in informal settlements often enjoy tenure security regardless of their legal status. In such space discretionary governance dominates rule-based governance. Several studies point out various non-legal factors that shape such de facto tenure security (Nakamura, 2017; Aristizabal \& Gomez, 2004; Gilbert, 2002; Payne, 2001; Razzaz, 1993; Varley, 1987). Furthermore, others argue that informal settlement residents' perception of their tenure security, rather than their legal or actual tenure security, influence their housing investment decisions (De Souza, 2001; Doebele, 1978; Reerink \& Van Gelder, 2010; Van Gelder, 2009, 2013; Van Gelder et al. 2015). During the field visit, it has also been informed by many slum dwellers that they pay annual utility bills to the local municipal corporation for the limited basic facilities they avail in slums. Consistent assurance from political parties against eviction, long-duration stay at the same location, payment of annual utility bills, the entitlement of various colored utility cards (like BPL card to take benefits of food security scheme) and Voter identity card mentioning name and address of the cardholder, motivate slum-dwellers to presume a "perceived sense of ownership of property rights" of their respective dwellings. Perceived property rights may persuade slum-dwellers to invest and upgrade their living standard.

On the other hand, the strong foothold of patronage in slums is responsible for the poor delivery of public goods. The patron offers discriminatory access to public and private goods and entitlements to the clients and also exploits their power to divert resources and basic 
amenities in their favor for electoral support or bribe. Preferably, the Patron diverts resources towards her existing political loyalists and potential supporters.

Focussed-Group Discussions (FGDs) conducted here revealed that the patron colludes with at least one dweller from each caste group, who plays the role of intermediary between the patron and clients. These intermediaries are nodes of information for the patron as well as for the clients. They provide basic services (processing of applications to get access to public and public provided private goods), collect bribes, shield the image of the patron whenever resentment comes open. Patron-client relationship generates private revenue for the patron, intermediary and in few cases for the clients through corruption. Klitgard (1988) synthesize the level of corruption in patron-client relationship as follows:

$$
\mathbf{C}=\mathbf{M}+\mathbf{D}+\mathbf{H}-\mathbf{A}
$$

Where, levels of Corruption (C) are proportional to Monopoly (M, the number of monopolistic positions in both the public and the private sector, implying the creation of economic rents), plus Discretion ( $\mathrm{D}$, the power to decide how to allocate rents), plus Hidden information $(\mathrm{H}$, the capacity to use as a resource in the corrupt exchange confidential information that can influence the allocation of rents), minus Accountability (A, the effectiveness of state and social monitoring of agents" conduct). In slums, the factor " $A$ " of the above relationship is very low or negligible as Brinkerhoff and Goldsmith (2002) comment that, "Patron-client relationships are prone to misunderstanding and manipulation because no independent entity keeps an eye on them". This encourages the patron to impose bribes on clients to award benefits to the latter of various government run schemes. The exchange of bribes and benefits of the public scheme is a reality in slums. In other words, fund allocation for constructing public goods turns into private revenue shared among the patron, intermediaries and clients.

Therefore, the quid-pro-quo relationship between the patron and the clients (i.e. the slum dwellers) is based on the exchange of public services and votes as well as a bribe. My point of contention is if the exchange relationship is based on the exchange of vote and public good provisioning only as discussed in most of the literature of patronage politics then slum improvement can be ensured easily. Rather, the central point is, a slum dweller is perceived as a potential client to accompany the interest groups in siphoning of the public funds, exclusively allocated for the former's development. One obvious question emerges here: Why do patrons take bribes from the clients who happen to be their voters too? Don't they get fear their possible defeat in the next election? Political parties secure votes through various other measures too.

In the next section, we attempt to identify various determinants behind slum dwellers' access to improved sanitation i.e. toilet facility. Lack of improved sanitation is a slum characteristic/deprivation while its removal is a step towards de-slumming a city. Provisioning of toilets under the broad ambit of sanitation is a public good although, for an individual household, a toilet is a private good. Hygienic separation of human waste from human contact is the central motive behind this provision. Constructing a toilet in the house with such a feature is an investment in the economy as it does not only provide direct benefits to household members, but it creates positive social externalities. The direct and indirect benefits are associated with a reduction in health expenditure, malnourishment, and productivity augmentation. Andres, et al. (2014) in their study on children health in rural India found that there is a 47 percent reduction in diarrhea prevalence between children living 
in a household without access to improved sanitation in a village without coverage of improved sanitation and children living in a household with access to improved sanitation in a village with complete coverage. One-fourth of this benefit is due to the direct benefit leaving the rest to external gains. Günther and Fink (2010) combined 172 Demography and Health Survey data sets from 70 countries to estimate the effect of water and sanitation on child mortality and morbidity water and sanitation infrastructure lowers the odds of children suffering from diarrhea by 7-17 percent and reduces the mortality risk for children under the age of five by about 5-20 percent. The authors also find evidence for the Mills-Reincke Multiplier for both water and sanitation access as well as positive health externalities for sanitation investments. In India, in 4,041 statutory towns, 7.9 million households do not have access to toilets and defecate in the open. Weak sanitation has significant health costs and untreated sewage from cities is the single biggest source of water resource pollution in India (Census, 2011). Therefore, private construction of toilets creates positive externalities in the slums in terms of health improvement and reduction in health expenditure. According to GoI (2015), 80\% of urban households engaging in open defecation. In India, the government has launched Swachh Bharat Abhiyan in 2014 with one of its objectives to make India Open Defecation Free (ODF) by $2^{\text {nd }}$ October 2019, through the allocation of funds to construct toilets in rural and urban areas. Slum dwellers are the natural beneficiary of this scheme.

\section{Data: Source and Elementary Analysis}

This study was conducted in Gaya, the second largest city of Bihar in India. According to Census 2011, the city comprises 41 slums which shelter 6.6 percent of the city's population. As per the information received from the municipal corporation of Gaya, 17 slums are located on State Government land, 5 on Central Govt. and the remaining 19 are on private or trust land. The study utilizes household level primary data of 184 households living in 9 different slums of Gaya. The data were collected through detailed household questionnaires and FGDs in each of the nine slums. The household level primary data columns demographic variables, slum characteristics, occupation of members of the household, access to basic amenities and public schemes, ownership of dwelling, years spent in slums, income, expenditure, etc. 52 percent of our respondents were female between the ages of 19-70 while male respondents were between the ages of 20-80. The average age of our respondents was 37 years. More than 99 percent of the sample households migrated from nearby villages of the Gaya district of Bihar. The average number of household members of the sample is 5.8 among which 95 households have more than 5 members (ranges from 6 to 24 members). The average number of household members for these 95 households is 7.3. Among 184 households, 64 own toilets within their household premises. Among them, 47 received funds from the Swachh Bharat Abhiyan. Of those who receive funds from Swachh Bharat Abhiyaan, 42 of them complain bribes paid to the ward councilor through the intermediary. The rest 22 constructed toilets with their private funds before this scheme got launched. 120 households who didn't receive funds informed rejection of their applications on some technical ground. 34 percent of our sample households avail of water facilities within their housing premise. 48 percent of households collect water within 50 meters distance from their dwelling while 18 percent collect water from 50-100 meters distance. In our data, 63.5 percent of households live in a pucca (concrete) house while the rest live in a Katcha house.

No household in the data being scrutinized owns legal land tenure for her dwelling. But, patron assurance against eviction, holding various government approved identity cards e.g. voter id cards, Aadhar cards, colored ration cards, etc. and annual utility bills in their names together help many slum dwellers to develop a false but strong perception that they cannot be 
dislodged from the present dwelling. During field visits, the respondents were asked about their land tenure status. 52 percent of our sample claims that they are the legal owner of the occupied space. The basis for their claim was the annual utility bills they pay to the municipal corporation. They also revealed that they are staying at the same location for generations, so they can't be evicted. The average number of years of stay of households is 37.5 while the median value is 40 years. This means that half of our sample households (i.e. 92) have been staying in slums for more than four decades. Long stay at the same location to assist slum dwellers in strengthening a false perception that they cannot be removed from their present location. This instigates them to carry out private investment. In our sample of 184 households, 106 households claim that they are staying on the same land for forty or more than forty years. Out of 106, 60 own a pucca house and 31 have a water source within their household premise.

Urban poor have the poor endowment of resources, but, rich in social capital. Sixty percent of the sample households maintain good bridging social relations while forty percent have earned strong bonded social capital in their slums. "Sharing of assets" is an asset in poor locations. For example, during the summer season, when there is an irregular water supply, slum dwellers receive help from those who have regular and improved water facilities within their premises. Slums in small cities are the replica of the rural social system as they migrate from nearby villages and live in caste-dominated small clusters in a slum and they possess strong bonding social capital. In slums, there are dwellings of those castes also whose population is meager to form a cluster thus they social dependency is more on bridging social capital.

\section{Model Specification}

If a dichotomous or categorical variable is involved in the analysis, we apply the logit model, and parameters are obtained through the maximum likelihood method. Cumulative Probability Density (CPD) function is presumed in the logit model:

$$
P=\frac{1}{1+\varepsilon^{-\left(\beta_{0}+\beta X_{i}\right)}}
$$

Where:

$P=$ Probability to access to toilet or not

$X i=$ Explanatory variables

$\varepsilon=$ Exponential value

$\beta=$ Parameters

The probability of access to a toilet is not directly observable. We have taken a binary dependent variable "access to the toilet" which refers to "if the household members go for open defecation or no access to the toilet within the dwelling premise $(=0)$ and own a toilet located within her dwelling premise $(=1)$. For the ease of exposition, we may write equation (2) as:

$$
P=\frac{1}{1+\varepsilon^{-\phi}}=\frac{\varepsilon^{\phi_{i}}}{1+\varepsilon^{\phi_{i}}} \text { Where: } \varphi=\beta_{0}+\beta_{i} X_{i}
$$

This equation shows the cumulative Logistic distribution function. If "P" the probability of employed worker is given by equation 2 , the probability of unemployed worker is: 


$$
(1-P)=\frac{1}{1+\varepsilon^{\phi_{i}}}=\frac{P}{1-P}=\frac{1+\varepsilon^{\phi_{i}}}{1+\varepsilon^{-\phi_{i}}}=\left(\frac{P}{1-P}\right)=\varepsilon^{\phi_{i}}
$$

$\left(\frac{P}{1-P}\right)$ indicates odds ratio. Taking the natural log of equation (4), we get:

$$
\ln \left(\frac{P}{1-P}\right)=\phi=\beta_{0}+\beta_{i} X_{i}
$$

Where $\mathrm{P}$ denotes the probability that ith respondent uses the toilet for defecation, $X i$ includes demographic and social variables, perceived legal tenure for the place of residence, and other control variables.

These parameters provide the effects of explanatory variables on the odds ratio so we estimate the marginal effects by taking the partial derivative of the probability of access to the toilet with respect to explanatory variables.

$$
\frac{\partial P}{\partial X_{i}}=\dot{P}_{j}\left(1-\dot{P}_{j}\right) \beta_{i}
$$

The sample households who have toilets within their dwelling premise they have constructed either through funds allotted through "Swachh Bharat Abhiyan" or with their private investment. In the data, of 184 households, only 64 households (30\%) have toilets facilities within their dwelling premises. The model is as follows:

$$
\begin{aligned}
\text { access to toilet }= & \beta_{0}+\beta_{1} \text { number hh members }+\beta_{2} \text { income groups }+\beta_{3} \text { years of education }+ \\
& \beta_{4} \text { distance of water source }+\beta_{5} \text { years of staying }+\beta_{6} \text { type of house }+ \\
& \beta_{7} \text { social capital }+\beta_{8} \text { perceived land tenure }+\beta_{9} \text { corrupt patronage }+\varepsilon
\end{aligned}
$$

Description of independent variables incorporated in the above model is as follows:

number hh members: The variable denotes the total number of members who live in a household. It is expected that the household having higher density, members are more likely to go for open defecation. Slum houses are illegal occupancies and there is a possibility that they have less space to build a toilet and prefer to go for open defecation.

income groups: The sample households are divided into three income groups (on monthly basis): Income: $0-5000=1,5001-10000=2$ and $>10000=3$. Upward income mobility enhances the households' capability to invest and motivates them to upgrade their living standard. It is expected that with a shift in income level, a household chooses to construct a toilet rather than go for open defecation.

years of education: This variable represents a number of years of formal schooling the head of the household completed. A number of years of schooling make people aware of hygienic practices like potential adverse consequences of open defecation. It is expected that a higher level of education may catalyze the toilet building.

distance of water source: This variable measure how far is the source of water from the household. A larger distance may incentivize a household to go for open defecation rather than to construct a toilet. The variable distance of water source is divided into three categories: If the water source is within the household premise $=1$, the water source is within 
the distance of 50 meters from the household $=2$ and source of water available at more than 50 meters distance $=3$.

years of staying: years of staying measures the length of time (in years), the household is staying at the said place. Staying at the same place for a longer period may help in strengthening the slum households' perception of secure land tenure and bring down the fear of the risk of long-term investment like toilet construction. Prolonged stay also assists in the accumulation of social capital and adaptation to the deprived life of slum etc.

type of house: This variable is a binary variable i.e. the slum dweller owns Katcha house $=1$ and Pucca house=2. Ownership of Pucca house carries few additional benefits: One, the household can upraise the house which may help them to reduce per room density; two, if the acquired space does not permit the household to construct a toilet, then it can be constructed on the roof of the house.

social capital: Strong social ties give voice to the slum dwellers to put pressure on local government to provide the basic infrastructure through various government schemes. The variable answers the question: "What kind of prevalent social ties do you maintain in your basti/colony?" social capital $=1$, if the household maintains better bonding ${ }^{5}$ social capital than bridging ${ }^{6}$ social capital and social capital $=2$ when reverse holds true.

\section{perceived land tenure:}

perceived land tenure $=1$ if the head of the household is convinced and aware of the reality that he/she doesn't legally own the land tenure

whereas, perceived tenure $=2$, when the head of the household holds false impression about the ownership of the dwelling space or they presume that they cannot be evacuated. This appears with payment of annual utility bill in name of the head of the dwelling for consumption of public goods in slums.

corrupt patronage: This variable is binary. corrupt patronage $=2$, when the respondent had paid a bribe to the local elected representative to get benefits through various government schemes, while corrupt patronage $=1$ when the respondent did not pay any bribe to get these benefits. Pecuniary corruption or political loyalty instigates the patron to make discriminatory decisions to ensure the funds get approved for the clients. In addition, limited funds allocated for various schemes give the patron the discretionary power to divert funds towards politically loyal clients. Here, it is not certain that the dwellers have been discriminated against or they were simply ineligible or denied due to limited funds. That's why bribe associated with patronage has been considered for analysis.

\section{Results and Discussions}

The given model aims to measure the likelihood of access to a toilet facility (or building a toilet) for slums' households and how the likelihood gets influenced by the chosen independent variables. This model potentially answers our central question i.e. why do slums persist? The variables which positively contribute to getting access to a toilet (through the public allocation of funds to build toilets) are the factors that play a significant role in the improvement of slums or eradication of slums through depletion of slum characteristics. But, we need to investigate those variables carefully as the potential determinant/s may be

\footnotetext{
${ }^{5}$ Refers to social ties within homogeneous groups. Here, it represents neighbours belong to same caste, family.

${ }^{6}$ Refers to social ties among heterogenous groups. Here, it represents neighbours belong to different castes.
} 
counterproductive and sustain the deprivations in slums. We have estimated the logit model whose results are in Table 2.

Table 2: Logit Estimates of Access to Toilet Facility

\begin{tabular}{|c|c|c|}
\hline Explanatory Variables & Coefficient & Odds-Ratio \\
\hline Intercept & $\begin{array}{c}-6.84677 * * * \\
(1.37555) \\
\end{array}$ & 0.001063 \\
\hline number hh members & $\begin{array}{l}-0.11839 \\
(0.08665)\end{array}$ & 0.888352 \\
\hline years of staying & $\begin{array}{c}0.07972 * * * \\
(0.01493) \\
\end{array}$ & 1.082979 \\
\hline years of education & $\begin{array}{l}0.11155^{*} \\
(0.04995) \\
\end{array}$ & 1.118006 \\
\hline \multicolumn{3}{|c|}{ Income Groups (Income: 0-5000=1) (Reference Category) } \\
\hline income groups 2 & $\begin{array}{c}0.34706 \\
(0.62779)\end{array}$ & 1.414897 \\
\hline income groups 3 & $\begin{array}{c}3.86823 * * * \\
(0.8941)\end{array}$ & 47.85772 \\
\hline \multicolumn{3}{|c|}{$\begin{array}{c}\text { Distance of Water Source: If Water Source is within Household Premises=1 } \\
\text { (Reference Category) }\end{array}$} \\
\hline distance of water source 2 & $\begin{array}{c}0.28593 \\
(0.49201) \\
\end{array}$ & 1.331005 \\
\hline \multicolumn{3}{|c|}{ Type of House: Slum dweller owns Katcha House=1 (Reference Category) } \\
\hline type of house 2 & $\begin{array}{c}1.89097 * * * \\
(0.59737)\end{array}$ & 6.625818 \\
\hline \multicolumn{3}{|c|}{$\begin{array}{c}\text { Social Capital: if the household maintains better bonding social capital than } \\
\text { bridging social capital=1 (Reference Category) }\end{array}$} \\
\hline socialcapital2 & $\begin{array}{l}-0.24201 \\
(0.44847)\end{array}$ & 0.785047 \\
\hline \multicolumn{3}{|c|}{$\begin{array}{l}\text { Perceived Land Tenure }=1 \text { if the head of the household is convinced and aware of } \\
\text { the reality that he/she doesn't legally own the land tenure (Reference Category) }\end{array}$} \\
\hline perceived land tenure2 & $\begin{array}{l}0.84814^{*} \\
(0.45797)\end{array}$ & 2.335296 \\
\hline \multicolumn{3}{|c|}{$\begin{array}{c}\text { Corrupt Patronage }=1 \text {, when the respondent did not pay any bribe to get these } \\
\text { benefits (Reference Category) }\end{array}$} \\
\hline corrupt patronage 2 & $\begin{array}{c}2.15025 * * * \\
(0.53138)\end{array}$ & 8.586983 \\
\hline \multicolumn{3}{|c|}{ Diagnostic Statistics } \\
\hline Null deviance & 254.01 & \\
\hline Residual deviance & 136.39 & \\
\hline AIC & 158.39 & \\
\hline
\end{tabular}

As expected, income groups, years of education, years of staying, corrupt patronage, perceived land tenure, and type of house is strongly associated with the likelihood to access to toilet facility in the households. In the logit model, it is relatively difficult (but not impossible) to discern from inspection of the coefficients how these variables combine to influence the probability of getting access to a toilet. To overcome the difficulty to interpret the marginal effects of an independent variable we take the help of a library called "effects" in software "R". "effect" displays the interaction of independent variables in the logit model fit to the data. The vertical axis is labeled on the probability scale, and a 95-percent pointwise 
confidence interval is drawn around the estimated effect. The function effect returns an object of class effect, containing information for constructing an effective display. The essential input to effect includes a linear $(\mathrm{lm})$ or generalized-linear $(\mathrm{glm})$ model object, and a term for which the effect is to be computed (Fox,2003). The effect displays of contributory variables are as follows:

Figure 1

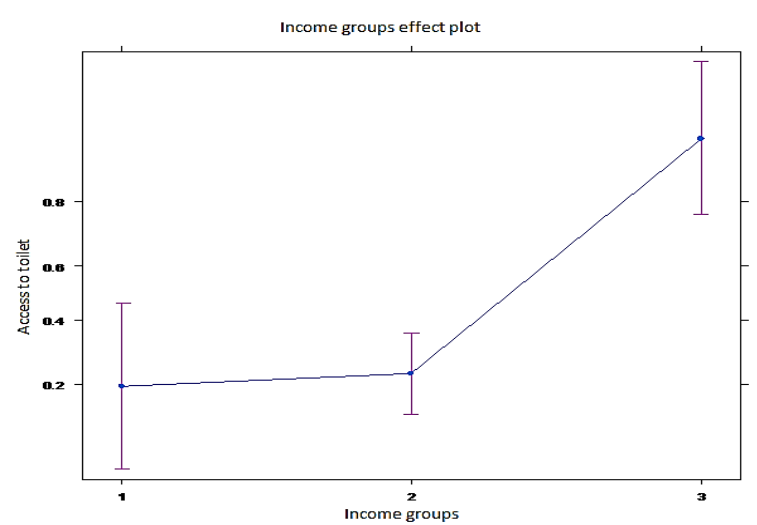

Figure 3

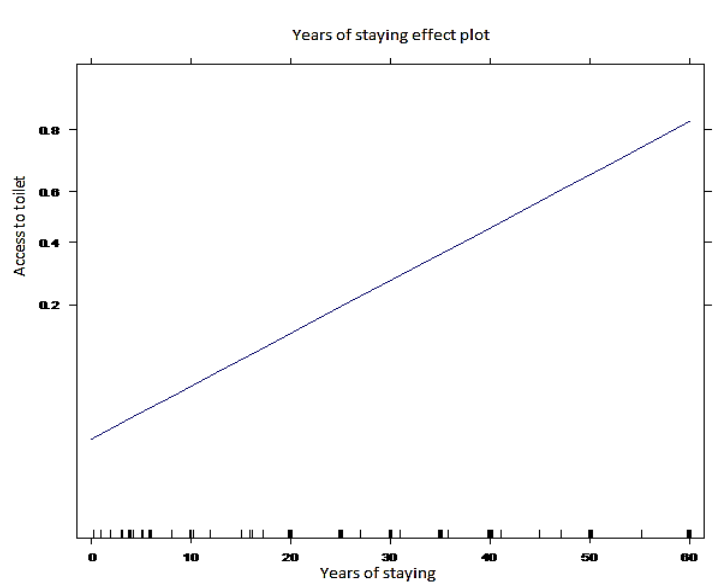

Figure 5

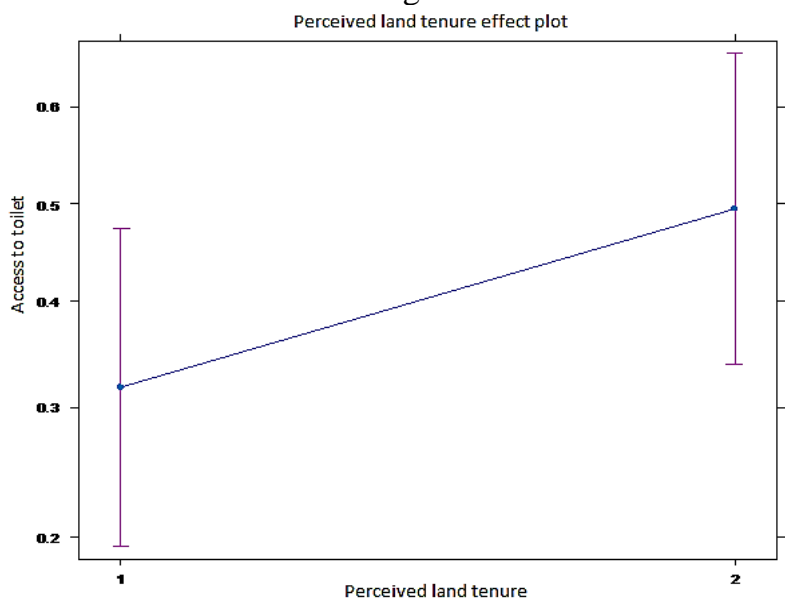

Figure 2

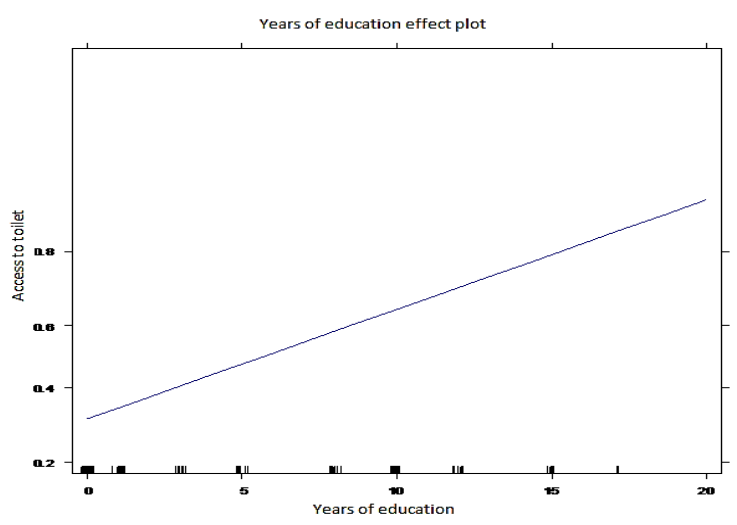

Figure 4

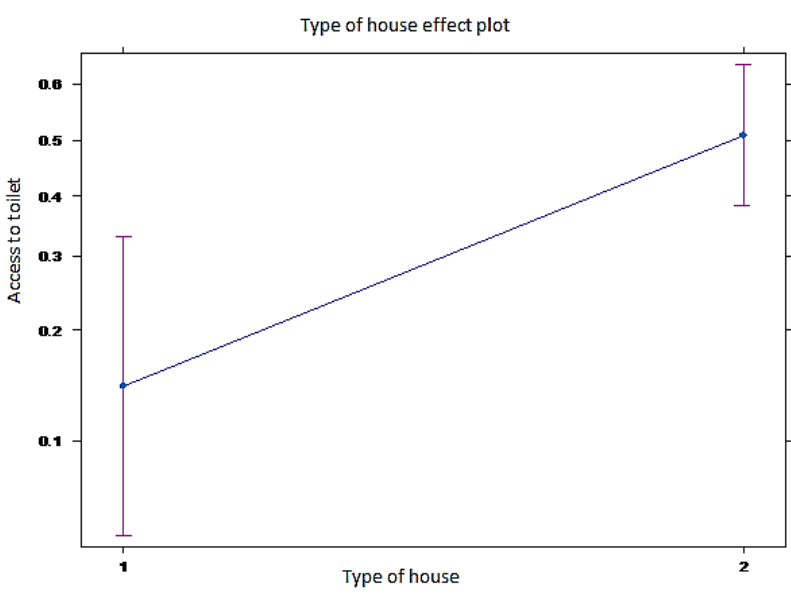

Figure 6

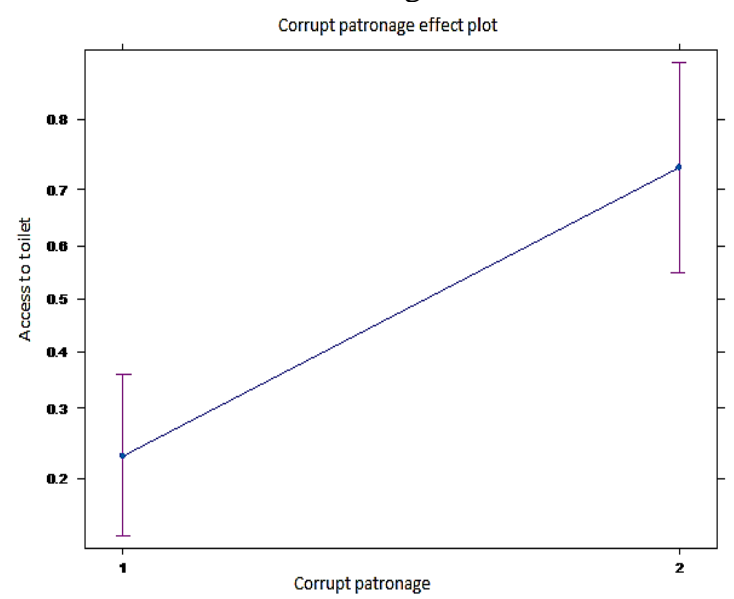


The above results illustrate that, with the rise in income, years of schooling, number of years of stay in the same dwelling, a household is more likely to access a toilet. In addition, corrupt patronage tied with bribe payment, perceived property rights and ownership of a pucca house increase the probability to get own toilet facility. Here, shift into higher income group appears as a very crucial determinant of access to a toilet, a proxy for slum improvement, when we control all other variables in the model. The above plot illustrates that income (monthly in Rs.) shift from level 1 (0-5000) to level 2 (5001-10000) do not enhance the probability (probability remains between 0.2 to 0.3 ) to access to the toilet but a sudden upsurge in probability can be observed (moves up to 0.8) with the shift to income level 3 $(>10000=3)$. As evident from the data, the mean income of our sample is Rs. 9700 per month while the median income is Rs.7500 per month. However, "take home" income per month for 18 percent of households is Rs 3,800. Assuming a household size of five, this implies that these households in the slums of Gaya are well below the poverty line. Only 24 percent of our sample households fall under the income level 3 (i.e.>10000). In our sample of 184, 64 households own toilets. Out of these 64, the income of 45 households falls in level 3, and among 45, 30 households own toilets and among 30, 13 claims that they paid a bribe to get funds approved for toilet construction. This indicates the preferential allocation of public funds in favor of comparatively higher income households. The above results indicate that a low probability to have own toilet is associated with households with lower income, whereas, rise in income potentially enhances the households' capability to invest. Engagement of workers in gainful employment with secure income may reduce the fiscal burden of the government and reduce the target group population to deliver benefits through various government schemes.

The above results show that households' heads who are illiterate or spent fewer years in school are less likely to have access to their toilet facility in comparison to households whose heads have spent more. In the sample, 52 percent of respondents are illiterate, 19 percent could not complete even primary education and only 16 percent received education till and post matriculation. In addition, 67 percent of women heads or women counterparts of the male heads are illiterate. The average years of schooling for the male head were 3.03 years while for the female counterpart of the male head and households with the only female head was 1.5 years.

It is also evident from the above results that, corrupt patronage enhances the likelihood of access to a toilet with smooth fund allocation to construct it. 28 percent of our respondents voiced discrimination and bribe payment against the ward councilor in the allocation of ration cards while 26 percent have paid a bribe to get funds approved for toilet construction under Swachh Bharat Abhiyan. Lack of improved sanitation is a deprivation defined in a slum's definition, which can be removed with the construction of a toilet. A significant proportion of allocated funds for toilet construction under Swachh Bharat Abhiyan is being paid as a bribe to the intermediary of the patron to get the funds approved to construct a toilet in each household. During our FGDs conducted in nine different slums, the discussants have made few startling revelations in the context of allocation of funds for running Swachh Bharat Abhiyan, a scheme to make India open defecation free. Mr. ' $A$ ' lives in a slum ' $\mathrm{X}$ ' narrates the reality during a focus group discussion as:

"Here, most of the slum dwellers go for open defecation. The intermediary of the ward councilor of our ward collected information like Aadhar card, Jan-dhan account details from many households with an assurance to approve funds for toilet construction. While interacting, he also took verbal assurance from us that a portion 
of money shall require to be paid as a bribe to municipal officials. The whole amount of the first installment, I paid him in the bank itself just after withdrawal, then I received the second installment after few weeks. The intermediary asked me to pay Rs. 500 more for accomplishing the process of fund disbursement. What can be done? The fund got approved only for those who assured bribe or are very close to the councilor. Those who didn't were disqualified. I got the money. I have bribed Rs. 4500. The rest of the amount was inadequate to build a toilet. I invested some of my own money and build it. How can you build a toilet after bribing a significant portion?"

Another dweller, Mr. 'B' added,

"In the same way, I too got money and constructed a toilet with some additional private fund. Toilet has been built but the toilet has no door. We have hanged a cloth there. I need to bring water also from the tap which is a hundred meters away."

In another slum, during focus group discussion, $\mathrm{Mr}$. ' $\mathrm{C}$ ' told the same story and added that

"...disqualification to get benefits of schemes is based on the private information about political loyalty with the ward councilor."

Focus group discussants also informed that, in case of getting funds for toilet construction, after payment of bribe the remaining fund remain insufficient to construct a toilet if not supplemented with their private funds. They inform that in few cases, clients utilize the remaining funds for their private consumption. In few other cases, the quality of public goods gets affected adversely. This appears counterproductive and restricts slum characteristics to deplete. The above discussion suggests that corrupt patronage tied with bribe payment and discriminatory allocation of public goods in slums produce a live case of fractured governance. Fractured governance is an aspect of government failure which potentially disrupts the welfare of the urban poor. In such societies, the moral cost of people is low, and corruption gets institutionalized.

In addition, prolonged stay at the same location encourages the slum dwellers for long-term investment. 52 percent of our sample households have a perceived sense of legal property rights for their land and 79 percent of them invested in pucca housing. Sixty percent of our sample households revealed that they are staying at the same place for at least three generations. Households staying at the same location for generations accumulate a significant amount of social capital which strengthens their perception about ownership of property rights. Longer years of stay at the same location, payment of annual utility bills for public good consumption in slums are non-legal factors that collectively develop and strengthen "perceived property rights". Stronger the perceived property rights, slum dwellers are more likely to invest in toilet construction. On the contrary, weaker the perceived property rights discourage households to invest in improved sanitation.

\section{Conclusions and Policy Discussions}

The study began with an argument that "persistence of slum characteristics is tantamount to the persistence of slums". In this direction, the study attempts quantitative and qualitative investigation, considering a case of access to a toilet, a proxy for a defined slum characteristic i.e. improved sanitation. Although, the study doesn't discuss other slum characteristics like 
lack of access to an improved water source, lack of sufficient living area and lack of housing durability the present description of the study would be helpful to understand the underlying dynamics behind persistence and removal of these characteristics. The presence of appallingly high illiteracy and a low level of education among slum dwellers prevent them to comprehend the importance of improved sanitation. Likewise, the low level of income of slum dwellers not only hinders the private investment but low-income households face exclusion while attempt to access public funds under the government scheme. This is evident from the sample that approximately 50 percent of the households who own toilets belong to the highest income strata among slum dwellers which represent 24 percent of the aggregate sample size. This biased distribution of public resources indicates that the coercive patronage in slums excludes the most deprived and plays a significant role in maintaining the slum characteristic. In addition, ingrained corruption in the patronage relationship yields poor quality public goods and adversely affects the consumption of poor slum dwellers as they supplement the investment with a private income. Therefore, local governance requires to be improved to access improved sanitation. The study finds the prominent role of "perceived property rights" in the removal of slum characteristics. Although, "perceived property rights are not the perfect substitute of 'legal property rights, but its role in slum improvement has been accepted by several authors (discussed in section II) whereas, Provision of legal land tenure in slums has been contradicted by several authors in recent years (e.g. Gilbert 2002, Mitchell 2005, Arimah and Branch, 2011; Ho, 2015). These studies caution that the allocation of legal property rights may not resolve the existing problems but potentially delivers other kinds of complexities. This issue requires more scrutiny and is beyond the purview of this paper. But, given the productive dimension of "perceived property rights", it would not be inappropriate to argue in favor of the provision of legal land tenure to the slum dwellers in the endeavor towards slum improvement.

The above stated discussion brings to the fore the role of human capital in catalyzing the process of slum improvement. Human capital development is an important determinant to enable slum improvement as it generates positive externalities, augments understanding to improve the quality of life and enhances productivity. Education makes people aware of the role of improved sanitation in health improvement and various government schemes for their development. Therefore, policies should be directed to engage slum dwellers to improve their human capital which would also enable them to earn higher wages and improve their economic status.

The slums studied in Gaya are settlements in either public or private trust land. Focus group discussions unveil that, although, slum dwellers receive notice from time to time for dislodgment the elected local representative with a handful of his associates in slums move to court against this and succeed. This helps them to win the confidence of slum dwellers and secure their vote share. In slums, the patron seeks vote in exchange of security against eviction and demand bribe in exchange of provisioning public goods. This appears contradictory but, further interrogation revealed that the slum dwellers are more concerned about their eviction rather than payment of a bribe. Slum dwellers also embrace the popular opinion that to get work done, one must pay a bribe. In other words, bribe payment is a norm in the governance structure in slums. Lack of legal land tenure, allows the political patronage to take its root in slums. Political patronage in slums is intimidating due to its monopoly power over the allocation of public goods and has wide policy implications. Effective delivery of public goods enhances private consumption through their positive external effects. Entrenched corruption with patronage in terms of preferential allocation of public good and bribe payment appears to be not only counterproductive but exclusionary. Payment of a 
significant portion of the allocated fund as a bribe to the patron does not only affect the quality of toilets but compels the clients not to construct the toilet with the remaining funds appear to be insufficient. The focus group discussants revealed a very startling fact that you can get funds to build a toilet only if either an individual pays at least 40 percent of the approved fund as a bribe or he is politically loyal to the ward councilor.

Our FGDs across slums unearthed one more interesting revelation about corruption. Another motivation behind bribe is the enactment of the Bihar Municipal Act, 2007 which provisioned up to 50 percent reservation to the women from Scheduled caste, Scheduled tribe, and other backward classes. The act directs the election commission to accept the principle of rotation in case of seat allotment to women from the above categories and unreserved categories. The winning candidate is not aware whether she/he would be able to contest the next election from the same ward/location or not. This insecurity might have induced them to take the bribe. These institutional factors are cumulatively affecting the effective implementation of "Swachh Bharat Abhiyan" adversely and play an instrumental role in maintaining the slum characteristics.

In sum, persistent miscarriage in providing good governance at the local level as reflected by the dominant presence of corrupt patronage, friction is rising on higher income path and low human capital accumulation are reasons behind the persistence of slums. The study proposes an improvement in the local level of governance and to implement income and human capital up-gradation measures to remove slum characteristics.

\section{References}

Ahluwalia, I. J. (2019). Urban governance in India. Journal of Urban Affairs, 41(1), 83-102.

Andres, L. A., Briceno, B., Chase, C., \& Echenique, J. A. (2014). Sanitation and Externalities: Evidence from Early Childhood Health in Rural India (Policy Research Working Paper).

Arimah, B. C., \& Branch, C. M. (2011). Slums as expressions of social exclusion: Explaining the prevalence of slums in African countries. UN-Habitat, Nairobi.

Aristizabal, N. C., \& Gómez, A. O. (2004). Improving security without titles in Bogotá. Habitat International, 28(2), 245-258.

Auerbach, A. M. (2016). Clients and Communities the Political Economy of Party Network Organization and Development in India's Urban Slums. World Pol., 68, 111.

Andrew, N., Ferguson, D., Wilkie, G., Corcoran, T., \& Simpson, L. (2009). Developing professional identity in nursing academics: The role of communities of practice. Nurse education today, 29(6), 607-611.

Banerjee, A., Kumar, S., Pande, R., \& Su, F. (2011). Do inform voters make better choices? Experimental evidence from urban India. Unpublished manuscript.

Banerjee, A., Pande, R., Vaidya, Y., Walton, M., \& Weaver, J. (2012). Delhi's slumdwellers: Deprivation, preferences and political engagement among the urban poor. London School of Economics, London: International Growth Centre Working Paper. Accessed October.

Brinkerhoff, D. W., \& Goldsmith, A. A. (2002). Clientelism, patrimonialism and democratic governance: An overview and framework for assessment and programming. US Agency for International Development Office of Democracy and Governance, 1-49.

Berenschot, W. (2010). Everyday mediation: The politics of public service delivery in Gujarat, India. Development and Change, 41(5), 883-905. 
Besley, T., \& Ghatak, M. (2006). Public goods and economic development. Understanding poverty, 19, 285-303.

Chandra, K. (2007). Why ethnic parties succeed: Patronage and ethnic head counts in India. Cambridge University Press.

Chandramouli, C., \& General, R. (2011). Census of india 2011. Provisional Population Totals. New Delhi: Government of India, 409-413.

Chong, A., \& Gradstein, M. (2007). Inequality and institutions. The Review of Economics and Statistics, 89(3), 454-465.

Datt, G., Murgai, R., \& Ravallion, M. (2016). Poverty reduction in India: Revisiting past debates with 60 years of data. Vox CEPR Policy Portal.

Dafe, F. (2009). No Business Like Slum Business? The Political Economy of the Continued Existence of Slums: A Case Study of Nairobi. The Political Economy of the Continued Existence of Slums: A Case Study of Nairobi.

Dasgupta, P., \& Ray, D. (1986). Inequality as a determinant of malnutrition and unemployment: Theory. The Economic Journal, 96(384), 1011-1034.

Deaton, A., \& Dreze, J. (2002). Poverty and inequality in India: a re-examination. Economic and political weekly, 3729-3748.

De Soto, H. (2000). The mystery of capital: Why capitalism triumphs in the West and fails everywhere else. Civitas Books.

De Souza, Flávio AM. (2001). Perceived security of land tenure in Recife, Brazil. Habitat International 25, no. 2 175-190.

Dixit, A. (2015). Governance reforms and growth: Some ideas from economic theory. Frontiers of Economics in China, 10(4), 567-584.

Doebele, W. (1978). Selected issues in urban land tenure. Urban land policy issues and opportunities, 1, 99-206.

Duflo, E., Galiani, S., \& Mobarak, M. (2012). Improving access to urban services for the poor: open issues and a framework for a future research agenda. J-PAL Urban Services Review Paper. Cambridge, MA: Abdul Latif Jameel Poverty Action Lab. http://www. povertyactionlab. org/publication/improving-access-urban-servicespoor,3.

Eisenstadt, S. N., \& Roniger, L. (1980). Patron--client relations as a model of structuring social exchange. Comparative studies in society and history, 22(1), 42-77.

Everest-Phillips, M. (2008). The Myth of 'Secure Property Rights': good economics as bad history and its impact on international development. London: Overseas Development Institute Working Paper.

Fox, J. (2003). Effect displays in $\mathrm{R}$ for generalised linear models. Journal of statistical software, 8(15), 1-27.

Fox, S. (2008, February). On the origins and consequences of slums. In Centre for the study of African economies economic development in Africa conference. Oxford, UK: Center for the Study of African Economies.

Gilbert, A. (2002). On the mystery of capital and the myths of Hernando de Soto: what difference does legal title make?. International development planning review, 24(1), $1-20$.

GoI (2015). Census 2011, Primary Census Abstract For Slum, downloaded from, http://www.censusindia.gov.in/2011-Documents/Slum-26-09-13.pdf

Gonzalez-Ocantos, E., De Jonge, C. K., Meléndez, C., Osorio, J., \& Nickerson, D. W. (2012). Vote buying and social desirability bias: Experimental evidence from Nicaragua. American Journal of Political Science, 56(1), 202-217.

Gunther, I., \& Fink, G. (2010). Water, sanitation and children's health: evidence from 172 DHS surveys. The World Bank. 
Ho, P. (2014). The 'credibility thesis' and its application to property rights:(In) secure land tenure, conflict and social welfare in China. Land Use Policy, 40, 13-27.

Jha, S., Rao, V., \& Woolcock, M. (2007). Governance in the gullies: democratic responsiveness and leadership in Delhi's slums. The World Bank.

Kaufmann, D., Kraay, A., \& Zoido, P. (1999). Governance matters. World Bank policy research working paper, (2196).

Khan, M. H. (2005). Markets, states and democracy: Patron-client networks and the case for democracy in developing countries. Democratisation, 12(5), 704-724.

Klitgaard R. (1988). Controlling Corruption, University of California Press.

Marx, B., Stoker, T., \& Suri, T. (2013). The economics of slums in the developing world. Journal of Economic perspectives, 27(4), 187-210.

Mahabir, R., Crooks, A., Croitoru, A., \& Agouris, P. (2016). The study of slums as social and physical constructs: Challenges and emerging research opportunities. Regional Studies, Regional Science, 3(1), 399-419.

Mitchell, T. (2004). The properties of markets: informal housing and capitalism's mystery. Institute for Advanced Studies in Social and Management Sciences. University of Lancaster. Cultural Political Economy Working Paper Series, Working Paper, 2.

Nakamura, S. (2017). Does slum formalisation without title provision stimulate housing improvement? A case of slum declaration in Pune, India. Urban Studies, 54(7), 17151735.

Payne, G. (2001). Urban land tenure policy options: Titles or rights?. Habitat international, 25(3), 415-429.

Piliavsky, A. (Ed.). (2014). Patronage as politics in South Asia. Cambridge University Press.

Razzaz, O. M. (1993). Examining property rights and investment in informal settlements: The case of Jordan. Land economics, 69(4).

Reerink, G., \& Van Gelder, J. L. (2010). Land titling, perceived tenure security, and housing consolidation in the kampongs of Bandung, Indonesia. Habitat International, 34(1), 78-85.

Robinson, J. A., \& Verdier, T. (2013). The political economy of clientelism. The Scandinavian Journal of Economics, 115(2), 260-291.

Ross, M. (2006). Is democracy good for the poor?. American Journal of Political Science, 50(4), 860-874.

Sharma, R. N., \& Bhide, A. (2005). World Bank funded slum sanitation programme in Mumbai: participatory approach and lessons learnt. Economic and Political Weekly, 1784-1789.

Tebaldi, E., \& Mohan, R. (2010). Institutions and poverty. The journal of development studies, 46(6), 1047-1066.

UN-Habitat (2016). Slum Alamnac, 2015 2016, Tracking Improvement in the Lives of Slum Dwellers, downloaded from https://unhabitat.org/wp-content/uploads/2016/02old/Slum\%20Almanac\%202015-2016_EN.pdf

Van Gelder, J. L. (2009). Legal tenure security, perceived tenure security and housing improvement in Buenos Aires: an attempt towards integration. International Journal of Urban and Regional Research, 33(1), 126-146.

Van Gelder, J. L. (2013). Then I'll Huff, and I'll Puff, and I'll...: A natural experiment on property titling, housing improvement and the psychology of tenure security. International Journal of Urban and Regional Research, 37(2), 734-749.

Van Gelder, J. L., \& Luciano, E. C. (2015). Tenure security as a predictor of housing investment in low-income settlements: testing a tripartite model. Environment and Planning A, 47(2), 485-500. 
Varley, A. (2002). Private or public: debating the meaning of tenure legalization. International Journal of Urban and Regional Research, 26(3), 449-461.

Wallack, J. S., Gaviria, A., Panizza, U., \& Stein, E. (2003). Particularism around the World. The World Bank Economic Review, 17(1), 133-143.

Weingrod, A. (1968). Patrons, patronage, and political parties. Comparative studies in Society and History, 10(4), 377-400.

Williamson, O. E. (2005). The economics of governance. American Economic Review, 95(2), $1-18$.

World Bank. (2003). World development report 2004: making services work for poor people. The World Bank.

Zhang, Y. (2018). The credibility of slums: Informal housing and urban governance in India. Land use policy, 79, 876-890. 